\title{
PHI-like Immunoreactivity in the Nervous System of the Cockroach (Insect) and Aplysia (Mollusc) with Special Reference to its Relationship to VIP-like Immunoreactivity*
}

\author{
Hirofumi Kuramoto, Ryogo Yui, Toshihiko Iwanaga, Tsuneo Fujita ${ }^{1}$ \\ and Noboru YANAIHARA ${ }^{2}$
}

Department of Anatomy (Prof. T. Fu JiTA) ${ }^{1}$, Niigata University School of Medicine, Niigata and Laboratory of Bioorganic Chemistry (Prof. N. Yanainara), ${ }^{2}$ Shizuoka College of Pharmacy, Shizuoka, Japan

Received June 15, 1985

\begin{abstract}
Summary. Studies in mammals have indicated that PHI (peptide histidine isoleucine) and VIP (vasoactive intestinal polypeptide) share a prepropeptide, and that both peptides are contained in the same neurons. The present study proposes that this relationship may not hold true in protostomian invertebrates. In the nervous system of the cockroach (Insecta, Arthropoda) and Aplysia (Gastropoda, Mollusca) distribution of PHI and VIP was examined by immunocytochemistry. In both animals neurons containing PHI-like immunoreactivity were numerously found and only a small part of them in the cockroach contained VIP-like immunoreactivity. These findings suggest that in these invertebrates, PHI may play a more important regulatory role than VIP. Possible reasons for the difference in the distribution of immunoreactivities for PHI and VIP are discussed.
\end{abstract}

Peptide HI (PHI) is a 27 amino acid neuropeptide isolated and characterized by TATEмото and Mutт (1981). Recently, PHM, the human counterpart of PHI has been revealed to be a part of the molecule of human preprovasoactive intestinal polypeptide (VIP) by sequence analysis of the mRNA. This has been confirmed by immunocytochemical studies, demonstrating in different mammals that immunoreactive VIP and PHI were contained in the same neurons (YANAIHARA et al., 1983; LuNDBERG et al., 1984).

VIP is a 28 amino acid neuropeptide widely distributed in the nervous system in vertebrates (SAID and RosENBERG, 1976; LARSSON et al., 1976), but its occurrence in invertebrates has been demonstrated in restricted animals. In the deuterostomian protochordate, Ciona intestinalis, it has been shown that some VIP-immunoreactive neurons occur in the cerebral ganglion (FRITSCH et al., 1982). In protostomian invertebrates, a small number of neurons in the subpharyngeal ganglion of the earthworm (Lumbricus terrestris) have been shown to contain an immunoreactive VIP (SUNDLER et al., 1977). In the pond snail, Lymnaea stagnalis, only two neurons have been positive for VIP (Schot et al., 1981). As for insects, a few neurons immunoreactive for VIP have been reported in the brain and extracerebral ganglia of the cockroach, Periplaneta americana

*This study was supported by a grant from the Ministry of Education, Science and Culture Japan (No. 59480090). 
(Fujita et al., 1981). VIP-positive nerve fibers have also been found in the longitudinal muscular layer of the gut in this insect (IwANAGA et al., 1981).

With regard to the occurrence of PHI in invertebrates, no paper is available as far as we are aware. The present paper demonstrates the distribution of immunoreactive $\mathrm{PHI}$ and VIP in the nervous tissues in two protostomian invertebrates, Aplysia and the cockroach. Special attention is given to the problem of whether both neuropeptides are co-stored in the same neurons as is the case in higher vertebrates.

A preliminary account of this study has been included in our paper (YUI et al., 1985 in press) presented to the International Symposium, “Nonmammalian Peptides," May 1985, Rome.

\section{MATERIALS AND METHODS}

The cockroach, Periplaneta americana (Insecta, Arthopoda), and Aplysia kurodai (Gastropoda, Mollusca) were used in the present study. The brain from the former and the cerebral ganglia from the latter were removed and fixed in Bouin's fluid. They were embedded in paraffin and cut serially at $3-5 \mu \mathrm{m}$. The sections, after deparaffinizing in xylene and washing in $0.01 \mathrm{M}$ phosphate buffered saline, $\mathrm{pH}$ 7.3, were subjected to the peroxidase-antiperoxidase (PAP) method (STERNBERGER, 1974).

Anti-PHI serum (R8201) and anti-VIP serum (R501) were raised in rabbits by injections of synthetic porcine PHI and porcine VIP, respectively. The dilution of the two antisera used was 1:3,000 (anti-PHI serum) and 1:1,600 (anti-VIP serum). The site of antigen-antibody reaction was revealed by porcine anti-rabbit IgG diluted at 1:20 (Dako, Denmark) followed by PAP complex diluted at 1:50 (Dako, Denmark).

The specificity of the immunoreaction was checked by conventional staining controls (STERNBERGER, 1974). In addition, an absorption test was performed using diluted antisera pretreated with synthetic porcine PHI and VIP at a concentration of 10-20 $\mu \mathrm{g} / \mathrm{ml}$ for $24 \mathrm{hr}$ at $4^{\circ} \mathrm{C}$.

\section{RESULTS}

\section{Cockroach Brain}

VIP-positive neurons were considerably few in number in the brain of the cockroach. A few VIP-positive cells $(10 \mu \mathrm{m}$ in diameter) were located in the lateral area of the protocerebrum (Fig. 1a). In the deutocerebrum, a few large cells $(20-30 \mu \mathrm{m})$ were positive for VIP in the lateral region (Fig. 2a).

PHI-positive cells were recognized more numerously than VIP-positive ones. In the protocerebrum, several PHI-positive cells $(15-30 \mu \mathrm{m})$ were found in the pars intercerebralis. Also in the lateral region, a few small cells $(10 \mu \mathrm{m})$ showed PHI immunoreactivity (Fig. 1b). In the deutocerebrum, several PHI-positive cells $(20-40 \mu \mathrm{m})$ were found in the lateral (Fig. 2a) and posterior regions.

By comparison of two consecutive sections, all the VIP-positive neurons in the brain showed PHI immunoreactivity (Fig. 1a, b). However, the majority of PHIpositive cells were found completely negative for VIP (Fig. 2a, b). Although numerous PHI-positive nerve fibers were identified in the brain, VIP-positive ones were found less frequently (Fig. 1a, b). 


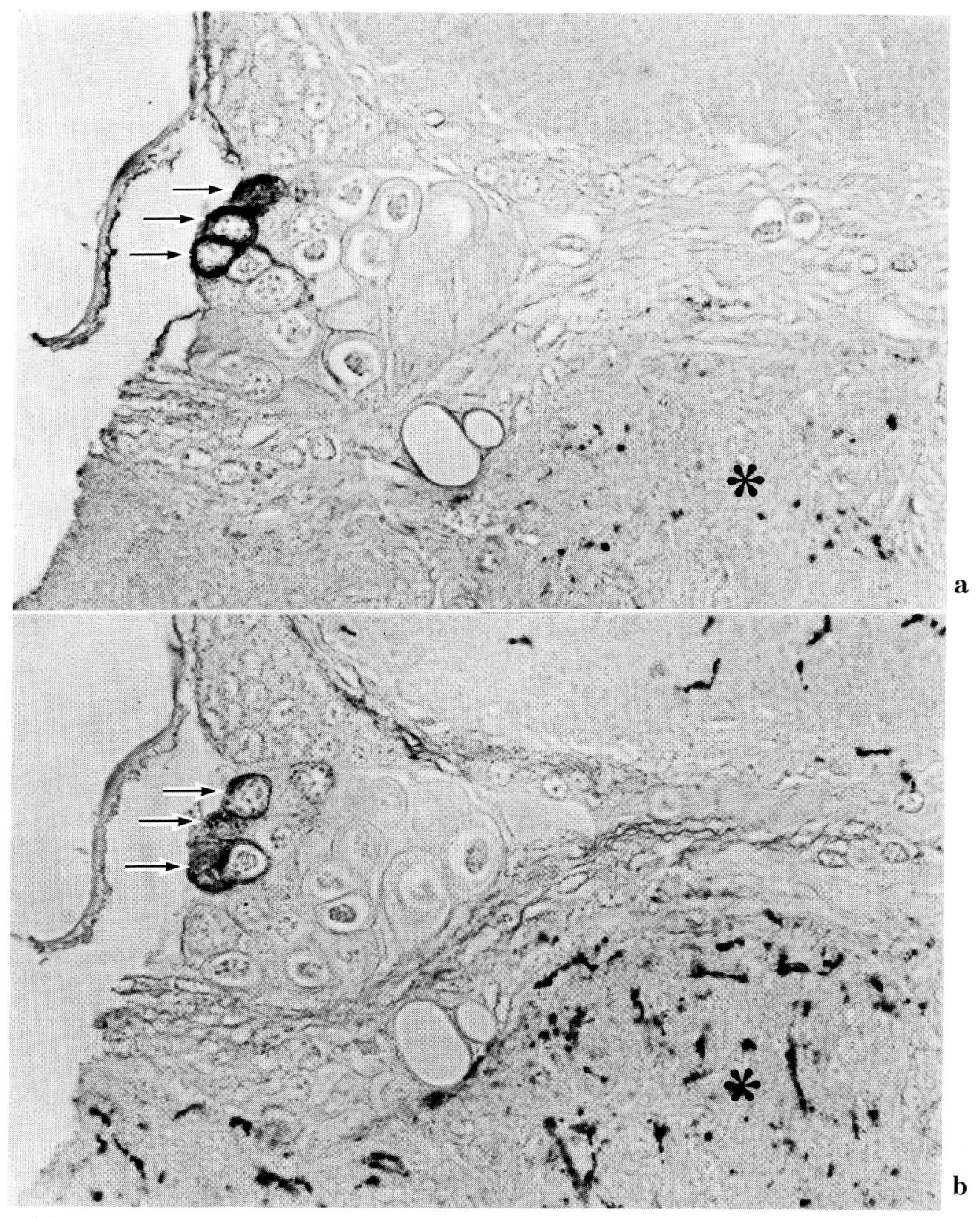

Fig. 1. a and b. Consecutive sections of the brain from a cockroach, immunostained for VIP (a) and PHI (b). Three small neurons (arrows) are immunoreactive to both antisera. Note also that PHI-positive nerve fibers are numerously seen(b), while VIP-positive ones are less frequent $(\mathbf{a})$ in the region indicated with asterisks $(*)$. Lateral area of the protocerebrum. $\times 560$ 


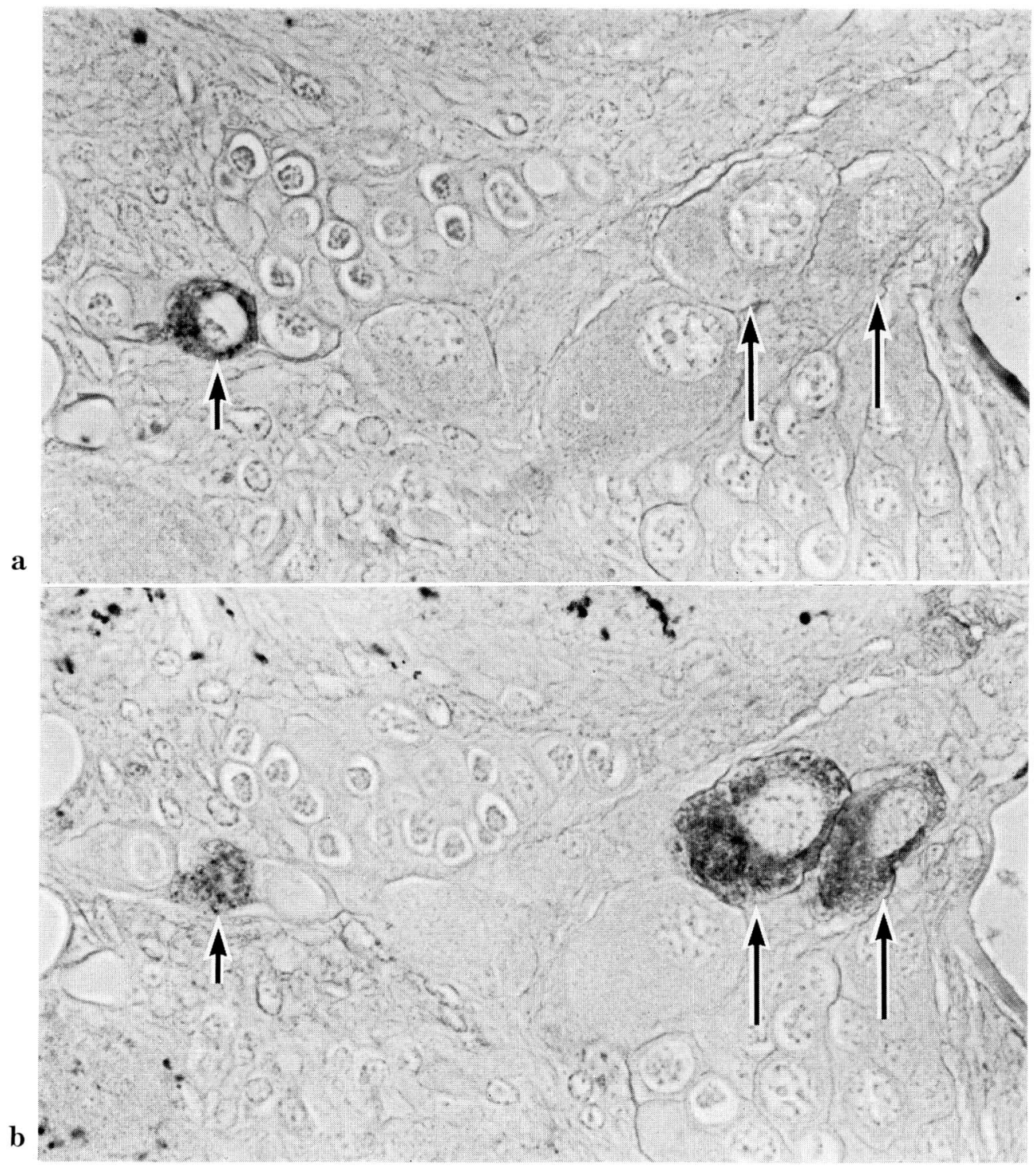

Fig. 2. a and b. Consecutive sections of the brain from a cockroach, stained with anti-VIP (a) and anti-PHI serum (b). Though a small neuron (short arrows) shows both immunoreactivities, two large ones (long arrows) are positive for PHI, but negative for VIP. In a lateral area of the deutocerebrum. $\times 560$

\section{Cerebral ganglion of Aplysia}

The cerebral ganglion of Aplysia was divided into eight cell clusters designated from A to $\mathrm{H}$ by Fredman and Jahan-Parwer (1975). According to their classification, PHIpositive cells were found in the $\mathrm{B}, \mathrm{C}$ and $\mathrm{F}$ clusters. In the $\mathrm{B}$ cluster, one large cell $(40 \mu \mathrm{m})$ and several small cells $(15-20 \mu \mathrm{m})$ were positive for PHI. In the C group, a few PHI-positive cells $(20 \mu \mathrm{m})$ were present (Fig. 3a). One large positive cell $(40 \mu \mathrm{m})$ was located in the F cluster. PHI-positive nerve fibers were numerously found in the cerebral ganglion (Fig. 3a). No VIP-positive neuron somata could be identified in the 


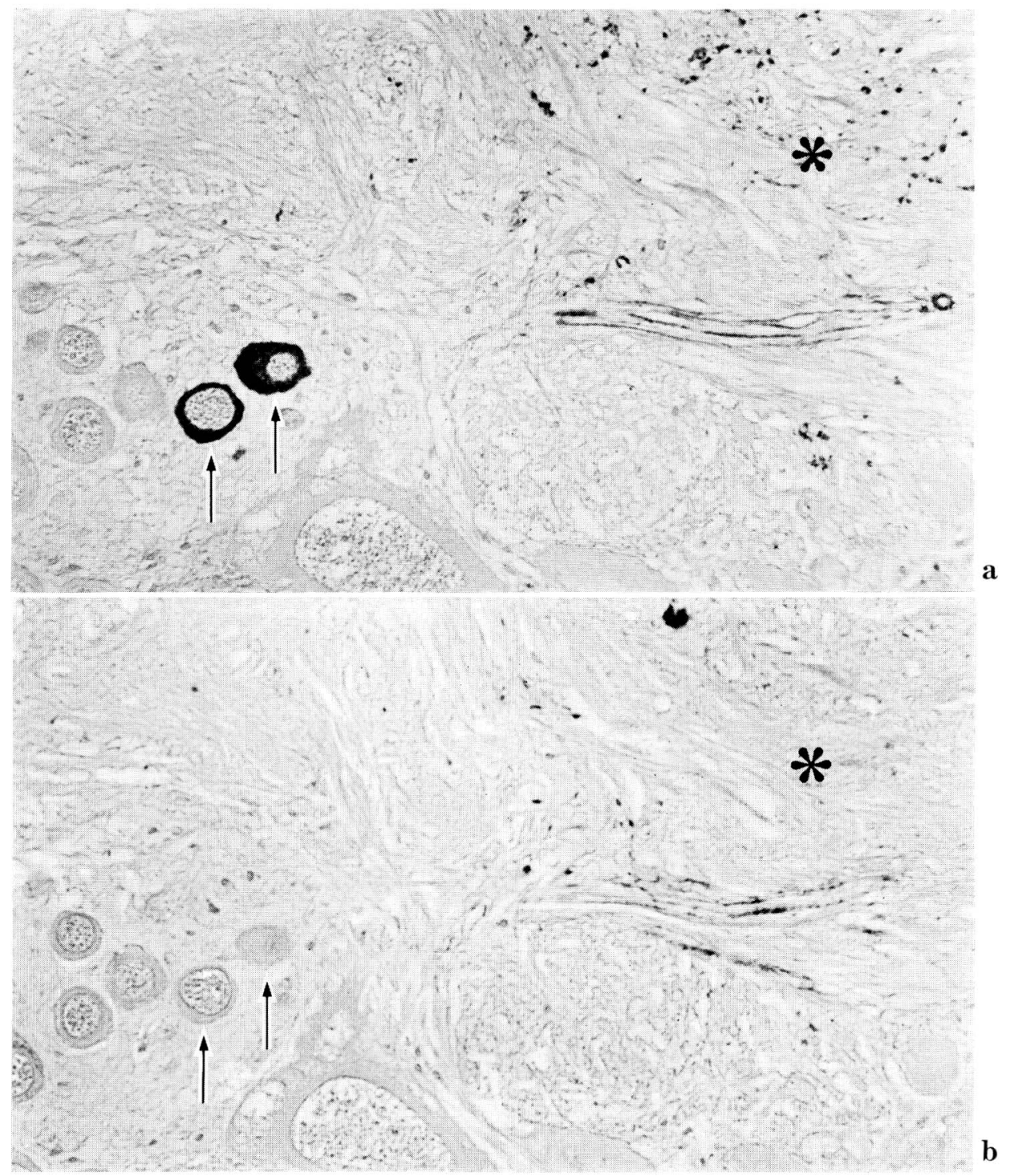

Fig. 3. a and b. Consecutive sections of the cerebral ganglion from Aplysia, immunostained for PHI (a) and VIP (b). Two PHI immunoreactive neurons (arrows) are negative for VIP. PHI-immunoreactive nerve fibres are present numerously, but VIP-immunoreactive ones are scarce in the area indicated with asterisks (*). C cluster of the cerebral ganglion. $\times 360$

cerebral ganglion, although a few VIP-immunoreactive nerve fibers were found (Fig. $3 b)$.

As the result of the absorption test, PHI immunoreactivity was completely inhibited by the anti-PHI serum pretreated with synthetic porcine PHI, but not influenced by that with synthetic porcine VIP. On the other hand, VIP immunoreactivity was abolished after incubation of the anti-VIP serum pretreated with synthetic porcine VIP, but not affected by the PHI-pretreated anti-VIP serum. 


\section{DISCUSSION}

In contrast to the co-existence of VIP and PHI in neurons in mammals, the present results indicate a large difference in the occurrence of both peptides. In the cockroach brain VIP immunoreactive neurons, which were rather few, were all immunoreactive for PHI, while there were numerous PHI-immunopositive neurons which were immunonegative for VIP. In Aplysia all PHI-immunoreactive neurons were negative for VIP.

This relationship reminds us of the findings by HöKFELT et al. (1982) in the rat that a large amount of immunoreactive PHI was contained in paraventricular neurons extending their fibers to the pericapillary spaces in the median eminence and yet only a few VIP-immunopositive fibers were detectable there. It may be thus possible that the rat PHI, when used as a neurohormone, is secreted without VIP. An alternative possibility is that in this neurosecretory system prepropeptides for PHI may not contain the amino acid sequence of VIP. The same possibilities may be conceivable to account for the difference in the distribution of PHI- and VIP-like peptides in invertebrates. Two neuron systems may be postulated thereby in the case of the cockroach: a small number of neurons producing PHI and VIP probably from a common precursor molecule and the remaining majority producing only PHI either via a different precursor or by a different processing mode.

The important finding in the present study is that a PHI-like peptide is contained in large amounts and in many neurons in the insect, cockroach and the mollusc, Aplysia, whereas a VIP-like peptide is detectable only in a few small neurons in the cockroach. The prevalence of a PHI-like peptide has also been found by us in the silkworm larva, Bombyx mori (insect) and Fusitriton oregonensis (Gastropoda, Mollusca) (YUI et al., 1985). In laboratory animals, PHI has been shown to possess weak VIP-like actions. LUNDBERG et al. (1984) claimed that in guinea pigs PHI is less potent as regards its hypotensive and bronchodilator effects as compared to VIP. Based on the present finding that a PHI-like peptide is distributed in the invertebrate nervous system in large amounts, it is reasonable to suggest that in these animals this peptide exerts more important regulatory actions than in mammals. The significance of PHI in lower animals would seem a worthwhile area to explore in a future study.

Acknowledgement. The authors wish to thank Dr. Y. Endo, Department of Anatomy, Yamanashi Medical College for kindly providing us with cockroaches.

\section{REFERENCES}

Fredman, S. M. and B. Jahan-Parwar: Synaptic connections in the cerebral ganglion of Aplysia. Brain Res. 100: 209-214 (1975).

Fritsch, H. A. R., S. Van Noorden and A. G. E. Pearse: Gastro-intestinal and neurohormonal peptides in the alimentary tract and cerebral complex of Ciona intestinalis (Ascidiaceae). Their relevance to the evolution of the diffuse neuroendocrine system. Cell Tiss. Res. 223: 369-402 (1982).

Fujita, T., R. Yui, T. Iwanaga, J. Nishiitsutsuji-Uwo, Y. Endo and N. Yanaihara: Evolutionary aspects of "brain-gut peptides": An immunohistochemical study. Peptides 2 (Suppl. 2): 123-131 (1981). 
Hökfelt, T., J. Fahrenkrug, K. Tatemoto, V. Mutt and S. Werner: PHI, a VIP-like peptide, is present in the rat median eminence. Acta physiol. scand. 116: 469-471 (1982).

Iwanaga, T., T. Fujita, J. Nishiitsutsuji-Uwo and Y. Endo: Immunohistochemical demonstration of PP-, somatostatin-, enteroglucagon- and VIP-like immunoreactivities in the cockroach midgut. Biomed. Res. 2: 202-207 (1981).

Larsson, L.-I., J. Fahrenkrug, O. Schaffalitzky de Muckadell, F. Sundler, R. Håkanson and J. F. Rehfeld : Localization of vasoactive intestinal polypeptide (VIP) to central and peripheral neurons. Proc. Nat. Acad. Sci. USA 73: 3197-3200 (1976).

Lundberg, J. M., J. Fahrenkrug, T. Hökfelt, C.-R. Martling, O. Larsson, K. Tatemoto and A. Änggård : Co-existence of peptide HI (PHI) and VIP in nerves regulating blood flow and bronchial smooth muscle tone in various mammals including man. Peptides 5: 593-606 (1984).

Said, S. I. and R. N. Rosenberg : Vasoactive intestinal polypeptide: abundant immunoreactivity in neural cell lines and normal nervous tissue. Science 192: 907-908 (1976).

Schot, L. P. C., H. H. Boer, D. F. Swaab and S. Van Noorden : Immunocytochemical demonstration of peptidergic neurons in the central nervous system of the pond snail Lymnaea stagnalis with antisera raised to biologically active peptides of vertebrates. Cell Tiss. Res. 216: 273-291 (1981).

Sternberger, L. A.: Immunocytochemistry. Prentice-Hall Inc., New Jersey, 1974.

Sundler, F., R. Håkanson, J. Alumets and B. Walles : Neuronal localization of pancreatic polypeptide (PP) and vasoactive intestinal peptide (VIP) immunoreactivity in the earthworm (Lumbricus terrestris). Brain Res. Bull. 2: 61-65 (1977).

Tatemoto, K. and V. Mutt: Isolation and characterisation of the intestinal peptide porcine PHI (PHI-27), a new member of the glucagon-secretin family. Proc. Nat. Acad. Sci. USA 78: 66033307 (1981).

Yanaihara, N., K. Nokihara, C. Yanaihara, T. Iwanaga and T. Fujita: Immunocytochemical demonstration of PHI and its co-existence with VIP in intestinal nerves of the rat and pig. Arch. histol. jap. 46: 575-581 (1983).

Yui, R., T. Iwanaga, H. Kuramoto and T. Fujita : Neuropeptide immunocytochemistry in protostomian invertebrates, with special reference to insects and molluscs. Peptide (1985, in press).

藏本博史

T951 新潟市旭町通 1

新潟大学医学部

第三解剖学教室
Dr. Hirofumi Kuramoto

Department of Anatomy

Niigata University School of Medicine

Asahimachi, Niigata

951 Japan 